Egyptian Journal of Rabbit Science, 27 (2): 289- 208(2017)

\title{
EFFECT OF PARTIAL REPLACEMENT OF BERSEEM HAY WITH BIOLOGICALLY TREATED CONOCARPUS ON REPRODUCTIVE PERFORMANCE OF RABBITS.
}

\author{
W.A.H. Ali; Fatma T.F. Abd-El Ghany; M.A. Mahmoud and Lamiaa F. \\ Abdel-Mawla \\ Animal Production Research Institute, Agricultural Research Center, Giza, Egypt.
}

The aim of the present study was to evaluate the effect of the partial replacement of berseem hay $(\mathrm{BH})$ by untreated and treated Conocarpus (CO) with Trichoderma reesi fungi (TR) and Effective microorganisms $\left(E M_{1}\right)$ on reproductive performance of Baladi Black (BB) rabbits. A total number of 105 does and 35 bucks BB, rabbits were randomly divided into seven dietary treatment groups (15 does + 5 bucks rabbits, each). Rabbits in the first group were fed a commercial pelleted diet was contained $25 \%$ berseem hay as a control group, while in the other six group rabbits fed diets contained 3.75 and $7.5 \%$ untreated and treated (CO) with Trichoderma reesi fungi (TR) or Effective microorganisms $\left(E M_{1}\right)$ to substitute 15 and $30 \%$ of BH of control ration.

The results show that rabbits fed diets contained $15 \% \mathrm{CO}+$ EMI and 15 or $30 \%$ CO+TR replacement of BH significantly $(P \leq$ $0.05)$ had higher weights for pregnancy, kindling and weaning stages compared to those on other dietary treatments. Moreover, feeding the does on diets contained $15 \% \mathrm{CO}+\mathrm{EM1}$ and with 15 or $30 \% \mathrm{CO}+\mathrm{TR}$ replacement of $B H$ significantly $(P \leq 0.05)$ gave the highest milk yield and content of dry matter, crude protein and fat compared to the other dietary treatments. Alike, the performance of the litters followed that obtained with corresponding does, where diets contained $15 \%$ $C O+E M 1$ and with 15 or $30 \% \mathrm{CO}+T R$ replacement of $\mathrm{BH}$ significantly $(P \leq 0.05)$ a cleaved the best figures for litter size of and weights from birth up to weaning that in turn revealed significant $(P \leq$ $0.05)$ decreased in mortality rate (\%) as compared to other dietary treatments. Nutrient digestibility coefficients were not significantly affected by dietary treatments. Values of total digestible nutrients $(T D N)$ were significantly $(P \leq 0.05)$ improved with dietary manipulation especially with fungal enrichment. 
Economically fortification of conocarpus diets with bacterial or fungal treatments gave higher net revenue compared to non-treated or the control diet.

Conclusively, it could be concluded from the present study that replacing $15 \%$ and $30 \%$ of berseem hay by biological treated conocarpus with fungi (Trichoderma reesi) or Effective microorganisms $\left(E M_{1}\right)$ in Baladi Black (BB) rabbit does diets, resulted in improve their reproduction performance without any adverse effect on physiological responses with high profitability under Egyptian conditions.

Key words: Reproductive performances, Berseem hay, Conocarpus, Trichoderma reesi fungi, Effective microorganisms.

Developing countries including Egypt are often suffered from animal protein deficiency. This is due to two main factors. The first is the small number of existing farm animals as compared to rapid growth of human population, and the second is the low productive and reproductive capabilities of these animals (Rowida et al., 2010). Reproductive performance optimization is considering one of the main factors that included high productivity on rabbit's farm (Friggens, 2003). Rabbit's production profitability depended on the number of rabbit's kindled / doe / year and postnatal survival of the kids. Nutrition is one of the major factors affecting the reproductive efficiency of rabbits during pregnancy and lactation (Castellini et al., 2010).

Feeding cost is the most expensive item in animal production cycle and reached about $70 \%$ from the total cost of rabbit industry (EL-Sayaad, 2002). Rabbit's nutritionists are looking for developing feeding strategies capable of reducing digestive diseases and high mortality while enhancing body condition of reproducing does therefore increasing their reproductive performances and increasing feed efficiency so lowering feeding and total production costs (Maertens, 2009).

Conocarpus is a large tree used to protect the farms in wide areas in Egypt from strong winds and dusts in desert. It belongs to the combretaceae family. It contains a lot of promoting compounds like protein, vitamins, minerals and large fiber content. Conocarpus also, contains antinutrition factors like tannins, total phenols and oxalates. Abd- El Ghany et al. (2016) reported that replacing $15 \%$ and $30 \%$ of berseem hay by biological treated conocarpus with fungus in growing rabbit's diet resulted in better performance and decreased the anti- nutrition factors without any 
adverse effect on physiological responses and carcass quality under Egyptian conditions with a low cost.

Therefore, this study aimed to investigate the effect of berseem hay replacement with conocarpus either with or without biological treated with Trichoderma reesi fungi or effective microorganisms (EM1) on some reproductive performance and physiological response of Baladi Black (BB) rabbits, under Egyptian condition.

\section{MATRIALS AND METHODS}

The present study was carried out at Borg El-Arab Experimental Station, Animal Production Research Institute, Ministry of Agriculture, Egypt. Two different levels of treated conocarpus with fungi (Trichoderma reesi) or Effective microorganisms $\left(\mathrm{EM}_{1}\right)$ were used to substitute 15 and $30 \%$ berseem hay $(\mathrm{BH})$ in the experimental diets. Table (1) shows formulations and chemical analysis of the experimental diets.

\section{Chemical composition of conocarpus:}

Untreated and treated tested material (Conocarpus) analyzed according to A.O.A.C (2005). Anti-nutrition factors measured according to Saman et al. (2016), data shown in Table 2.

\section{Biological treatments:}

Trichoderma reesi was obtained from the Microbial Chemistry Department, National Research Center, Dokki, Cairo, Egypt. The microorganisms were maintained on YMP agar medium. The inoculum were used to inoculate $500 \mathrm{ml}$ capacity conical flasks containing $20 \mathrm{~g}$ of cooled sterilized residue by (autoclaving at $121^{\circ} \mathrm{C}$ for 30 minutes) moistened by basal medium containing $4 \%$ molasses, $4 \%$ urea, $0.2 \%$ $\mathrm{KH}_{2} \mathrm{PO}_{4}$ and $0.03 \mathrm{MgSO}_{4} .7 \mathrm{H}_{2} \mathrm{O}$ and additives $0.05 \mathrm{~kg}$ yeast/ton in solid liquid ratio $1: 2$ by $10 \%$ (v/w) (El-Ashry et al., 2002).

The inoculated flasks were incubated in controlled temperature incubator at $30.0^{\circ} \mathrm{C} \pm 2.0$ in rotary shaker $150 \mathrm{rpm}$ for 48 hours. These inoculums were used to inoculate 50 liters containing 40 liters of sterilized medium containing the composition of the same above mentioned medium by $10 \%(\mathrm{v} / \mathrm{w})$ then incubated for 72 hours to produce $480 \mathrm{~g}$ fungi biomass. The $\mathrm{EM}_{1}$ is a product of EMRO Organization in Japan (EM ${ }_{1}$ Research Organization, Inc., Takamiyagi Bldg. 2F, 2-9-2 Gameko, Ginowan-Shi Okinawa, Japan).

\section{Experimental protocol:}

One hundred and five of Baladi Black (BB) rabbit does at 8-9 months of age and 35 bucks 9-10 month of age were used in this experiment. The 
ALI et al.

Table 1: Formulation and chemical analysis of experimental diets.

\begin{tabular}{|c|c|c|c|c|c|c|c|}
\hline \multirow{2}{*}{ Ingredients } & \multirow{2}{*}{$\begin{array}{c}\text { Control } \\
\text { diet }\end{array}$} & \multicolumn{2}{|c|}{$\begin{array}{l}\text { Conocarpus } \\
\text { (CO) }\end{array}$} & \multicolumn{2}{|c|}{$\mathrm{CO}+\mathrm{EM}_{1}$} & \multicolumn{2}{|c|}{$\mathrm{CO}+\mathrm{TR}$} \\
\hline & & $15 \%$ & $\begin{array}{l}30 \\
\%\end{array}$ & $15 \%$ & $30 \%$ & $15 \%$ & $30 \%$ \\
\hline Berseem hay & 25.00 & 21.25 & 17.5 & 21.25 & 17.5 & 21.25 & 17.5 \\
\hline Conocarpus & 0.00 & 3.75 & 7.5 & 3.75 & 7.5 & 3.75 & 7.5 \\
\hline Barley grains & 23.00 & 23.50 & $\begin{array}{c}23.7 \\
5\end{array}$ & 23.5 & 23.75 & 23.5 & 23.75 \\
\hline Wheat bran & 22.40 & 21.9 & $\begin{array}{c}21.6 \\
3\end{array}$ & 21.9 & 21.63 & 21.9 & 21.63 \\
\hline Yellow corn & 2.80 & 2.77 & 2.80 & 2.77 & 2.8 & 2.77 & 2.8 \\
\hline Soybean meal $(44 \%)$ & 21.30 & 21.30 & $\begin{array}{c}21.3 \\
0\end{array}$ & 21.30 & 21.30 & 21.30 & $\begin{array}{l}21 . \\
30\end{array}$ \\
\hline Methionene & 0.10 & 0.10 & 0.10 & 0.10 & 0.10 & 0.10 & 0.10 \\
\hline *Premix & 0.30 & 0.30 & 0.30 & 0.30 & 0.30 & 0.30 & 0.30 \\
\hline Lime stone & 1.60 & 1.65 & 1.67 & 1.65 & 1.67 & 1.65 & 1.67 \\
\hline Molasses & 3.00 & 3.00 & $\begin{array}{l}3 . \\
00\end{array}$ & 3. 00 & 3. 00 & 3. 00 & 3. 00 \\
\hline $\mathrm{NaCl}$ & 0.50 & 0.48 & 0.45 & 0.48 & 0.45 & 0.48 & 0.45 \\
\hline Total & 100 & 100 & 100 & 100 & 100 & 100 & 100 \\
\hline \multicolumn{8}{|l|}{ Chemical analysis } \\
\hline DM & 86.54 & 86.53 & 86.91 & 87.20 & 88.17 & 88.12 & 88.30 \\
\hline OM & 92.25 & 92.33 & 91.6 & 90.47 & 90.24 & 90.27 & 90.25 \\
\hline CP & 18.04 & 18.06 & 18.00 & 18.06 & 18.00 & 18.06 & 18.00 \\
\hline $\mathbf{C F}$ & 10.60 & 10.55 & 10.50 & 10.48 & 10.45 & 10.43 & 10.40 \\
\hline $\mathbf{E E}$ & 2.14 & 2.04 & 2.02 & 1.99 & 1.93 & 2.01 & 2.06 \\
\hline NFE & 61.47 & 61.68 & 61.08 & 59.94 & 59.86 & 59.77 & 59.79 \\
\hline Ash & 7.75 & 7.67 & 8.40 & 9.53 & 9.76 & 9.73 & 9.75 \\
\hline NDF & 35.89 & 35.86 & 35.82 & 35.81 & 35.79 & 35.78 & 35.76 \\
\hline ADF & 17.93 & $\begin{array}{r}21.12 \\
5.56\end{array}$ & 22.64 & 20.04 & 20.87 & 18.55 & 19.05 \\
\hline ADL & 5.72 & $\begin{array}{r}5.56 \\
2509\end{array}$ & 5.34 & 5.31 & 5.30 & 5.27 & 5.21 \\
\hline DE & 2597.80 & 2599. & 2601.23 & 2601.73 & 2602.71 & 2603.20 & 2604.18 \\
\hline $\mathrm{C} / \mathrm{P}$ ratio & 144 & $\begin{array}{c}27 \\
144\end{array}$ & 144 & 144 & 144 & 144 & 144 \\
\hline
\end{tabular}

*Each1.5 kg of vitamins and minerals mixture contains: Vit. A 10.000.000 IU, Vit. $B_{1}$ $1000 \mathrm{mg}$, Vit. $B_{2}$ 5000mg, Vit. $D_{3} 2.000 .000 \mathrm{IU}$, Vit E $10.000 \mathrm{mg}$, Vit. $\mathrm{K}{ }_{3} 1000 \mathrm{mg}$, Pantothenic acid 10.000mg; Nicotinic acid, 30.000g; Vit. $B_{6} 15000 \mathrm{mg}$; Vit. $B_{12} 10 \mathrm{mg}$, Folic acid 1.0g, Biotin $50 \mathrm{mg}, \mathrm{Cu} 4 \mathrm{~g}$, choline chloride 200mg, Mn 60g, Fe 30g, , Co $0.1 \mathrm{~g}$, Se $0.1 \mathrm{~g}$, Zn 50 g,Iodine $0.3 \mathrm{~g}$ and Antioxidant 10.000mg. According to Feed Composition Tables for animal and poultry feedstuffs used in Egypt (2001).

$* * \mathrm{DE}(\mathrm{Kcal} / \mathrm{kg})=4.36-0.0491 \mathrm{x}$ NDF\% . Where, NDF\% $=28.924+0.657 \mathrm{x}$ CF\% (Calculated according to Cheeke, 1987).

$\mathrm{CO}=$ Untreated Conocarpous, EM1 = Effective microorganisms, TR.= Trichoderma reesi fungi. 
Table 2: Chemical analysis of untreated and treated conocarpus with EM1 and Fungus.

\begin{tabular}{cccc}
\hline Items & CO & CO+EM $_{\mathbf{1}}$ & CO+TR \\
\hline DM & 90.22 & 93.11 & 93.01 \\
OM & 85.13 & 80.15 & 79.56 \\
CP & 15.28 & 20.22 & 22.26 \\
EE & 2.30 & 1.91 & 1.88 \\
NFE & 54.20 & 47.77 & 46.37 \\
Ash & 14.87 & 19.85 & 20.44 \\
CF & 20.35 & 18.25 & 18.05 \\
NDF & 77.80 & 80.81 & 85.30 \\
ADF & 52.91 & 50.38 & 47.83 \\
ADL & 12.01 & 10.62 & 9.87 \\
\hline Anti-nutritional factors & & & \\
Tannins & 2.36 & 2.12 & 1.99 \\
Total phenols & 2.03 & 1.79 & 1.32 \\
oxalates & 1.22 & 0.89 & 0.77 \\
\hline
\end{tabular}

$\mathrm{CO}=$ Untreated Conocarpous, EM1 = Effective microorganisms, TR.= Trichoderma reesi fungi.

does and bucks were randomly divided into seven experimental dietary treatment groups (15 does +5 bucks rabbits each), with approximately similar initial body weights. Rabbits were fed the experimental diet to meet their nutrient requirements during the growing period according to Agriculture Ministry Decree (1996) recommendations.

Cycle of 16 hours of light and 8 hours of dark were used throughout the experiment. All does were kept under the same management condition and were presented to males seven days after kindled. Fourteen days after mating, does were tested for pregnant by abdominal palpation. Non-pregnant rabbit does were re-mated. The experimental period included three reproductive cycles. Animals were housed in individual cages provided with rations, nest boxes and automatic nipple drinkers.

\section{Measurements:}

Feed intake (FI) of rabbit does were recorded daily and litters weight was measured weekly. Suckling kits were allowed to eat the same diet as their mother and were weaned at 35 days of age. Lactating rabbit does (five / group) were used to measure milk production and it's composition. Rabbit does were separated from their kids after parturition and controlled suckling was applied. To prevent free nursing, does were placed in cages next to the nest box. Litter sizes (LS) of kits were kept constant throughout lactation. Milk production was 
estimated daily from weight loss of rabbit does after suckling (Mohamed et al., 2016).

Milk production was assessed at $7^{\text {th }}, 14^{\text {th }}, 21^{\text {st }}$ and $28^{\text {th }}$ day of lactation. Kids were separated from their mothers to prevent suckling for a period of 24 hours before samples collection in the morning. The chemical composition of diets and milk at 21 days of lactation were analyzed according to methods of A.O.A.C (2005) as shown data in Table 5.

\section{Digestibility trail:}

Digestibility trail was carried out to determine the digestion coefficients and nutritive value, using three bucks from each treatment. Feces were collected daily, weighed and dried at $60{ }^{\circ} \mathrm{C}$ for $48 \mathrm{hrs}$, finely ground and stored for chemical analysis. Data of quantities and chemical analysis of feed and feces were used to calculate the nutrients digestion coefficients and the nutritive values of the dietary treatments, as described by Cheeke et al. (1982). The samples of feed and feces were daily recorded for chemical analysis according to A.O.A.C. (2000). Neutral Detergent Fiber (NDF), Acid Detergent Fiber (ADF) and Detergent Lignin (ADL) were determined by method of Van Socest (1982), as shown data in Table 8.

\section{Economic efficiency (EEF):}

The percentage of (EEF) was calculated according to price marketing during, 2017. Data shown in (Table,9).

\section{Statistical analysis:}

Data were statistically analyzed according to SAS (2001) computer program using the following fixed model: $Y_{i j}=\mu+T_{i}+e_{i j}$

Where: $Y_{i j}=$ An observation; $\mu=$ Overall mean; $T_{i}=$ Effect of treatments; $e_{i j}$ $=$ Random error component assumed to be normally distributed. Duncan's multiple range tests was performed (Duncan, 1955) to detect significant differences between means.

\section{RESULTS AND DISCUSSION}

\section{Chemical composition of conocarpus:}

Table 2 shows that, untreated conocarpus (CO) contained DM, OM, CP, EE, NFE, Ash and CF as 90.22, 85.13, 15.28, 2.30, 54.20, 14.87 and 20.35, respectively. Treated Conocarpus with $\mathrm{EM}_{1}$ contained DM, OM, CP, EE, NFE, Ash and CF as 93.11, 80.15, 20.22, 1.91, 47.77, 19.85 and 18.25, respectively. while, treated Conocarpus with TR contained 93.01, 79.56, 22.26, 1.88, 46.37, 20.44 and 18.05, respectively. Tannins, Total phenols 
and oxalates decreased from 2.36, 2.03 and 1.22 respectively in untreated Conocarpus to $2.12,1.79$ and 0.89 respectively in CO+ EM1 and to 1.99, 1.32 and 0.77 respectively in CO+TR. These results may be related to the effect of biological treatment in hydrolyzing the cellulose and breaking the lingo-cellulose bonds (Abd- El Ghany et al., 2016).

\section{Growth performance:}

Table 3 shows effect of treatments on body weight at mating, pregnancy, kindling, weaning, also, feed intake (g/day) at pregnancy and lactation. It is noting that rabbits fed diets contained treated conocarpus with fungus or $\mathrm{EM}_{1}$ significantly $(\mathrm{P} \leq 0.05)$ had increased in body weight at pregnant, kindling, weaning, and also, feed intake at pregnant and lactation periods than those fed the other experimental diets. Rabbits fed diets of $15 \%$ and $30 \%$ of $\mathrm{BH}$ replaced by conocarpus treated with fungus were significantly $(\mathrm{P} \leq 0.05)$ consumed more feed intake than those fed the other experimental diets. The improvement in rabbit does performance during pregnancy and lactation periods may be due to an increase in the efficiency of nutrients utilization. These results agree with Xiccato et al. (2004) who reported increasing in BW, FI and milk production of rabbit does with using balanced fibrous dietary diets. That, diets included balanced nutrients composition especially in the domain of fibrous components gave a highest performance possible in term of production or feed efficiency (Gidenne, 2000; Fortun-Lamothe and Gidenne, 2003).

\section{Milk yield:}

Data tabulated in Table 4 clearly show that feeding the does on diets contained $15 \% \mathrm{CO}+\mathrm{EM} 1$ and with 15 or $30 \% \mathrm{CO}+\mathrm{TR}$ significantly $(\mathrm{P} \leq$ $0.05)$ gave the highest milk yield compared to the other dietary treatments. These results are in agreement with Gaafar et al. (2014) who reported that during lactation, milk production was greater in does fed on fibrous dietary diets. Also, results confirm that generally, rabbit's milk yield shows gradual increase until $21^{\text {th }}$ day of lactation; afterwards it decreases by next 10 days (Lukefahr et al., 1983 and Chrastinova et al., 1997). Also, EL-Sayaad, (1994) reported that the increasing in the litter size seemed to induce stimulation for mammary glands to produce high milk quantity. Moreover, Linzell et al. (1972) found that an increased suckling intensity in large litters may be allow more complete evacuation remainder milk, through greater oxytocin release due to increase afferent nerve stimulation of the teats. However, Abo-El-Ezz et al. (1981) mentioned that inconsistent in milk yield increased by increasing the litter size. Besides that the increasing in 
Table 3: Effect of treatments on does performance during pregnancy and lactation.

\begin{tabular}{lccccccc}
\hline \multirow{2}{*}{ Items } & Control & \multicolumn{2}{c}{ CO } & \multicolumn{2}{c}{ CO+EM } & \multicolumn{2}{c}{ CO+TR } \\
\cline { 3 - 8 } & diet & $\mathbf{1 5 \%}$ & $\mathbf{3 0 \%}$ & $\mathbf{1 5 \%}$ & $\mathbf{3 0 \%}$ & $\mathbf{1 5 \%}$ & $\mathbf{3 0 \%}$ \\
\hline \multirow{4}{*}{ Mating } & 3000 & 3024 & 3017 & 3021 & 3020 & 3023 & 3018 \\
& \pm 25.47 & \pm 24.11 & \pm 25.26 & \pm 23.61 & \pm 22.78 & \pm 24.69 & \pm 22.97 \\
pregnan & $3315^{\mathrm{b}}$ & $3310^{\mathrm{b}}$ & $3300^{\mathrm{b}}$ & $3500^{\mathrm{a}}$ & $3400^{\mathrm{ab}}$ & $3550^{\mathrm{a}}$ & $3525^{\mathrm{a}}$ \\
& \pm 25.11 & \pm 25.69 & \pm 25.26 & \pm 26.34 & \pm 23.12 & \pm 26.47 & \pm 25.14 \\
& $2767^{\mathrm{b}}$ & $2705^{\mathrm{b}}$ & $2700^{\mathrm{b}}$ & $2900^{\mathrm{a}}$ & $2890^{\mathrm{ab}}$ & $2950^{\mathrm{a}}$ & $2930^{\mathrm{a}}$ \\
\multirow{2}{*}{ kindling } & \pm 25.94 & \pm 24.37 & \pm 24.96 & \pm 25.64 & \pm 24.87 & \pm 25.34 & \pm 24.97 \\
& $2690^{\mathrm{b}}$ & $2615^{\mathrm{c}}$ & $2600^{\mathrm{c}}$ & $2810^{\mathrm{a}}$ & $2774^{\mathrm{ab}}$ & $2867^{\mathrm{a}}$ & $2851^{\mathrm{a}}$ \\
\multirow{2}{*}{ Weaning } & \pm 25.19 & \pm 25.02 & \pm 24.96 & \pm 24.34 & \pm 25.22 & \pm 25.72 & \pm 25.72
\end{tabular}

Feed intake (g/d)

\begin{tabular}{|c|c|c|c|c|c|c|c|}
\hline \multirow{2}{*}{$\begin{array}{l}\text { Pregnant } \\
\text { does }\end{array}$} & $189.64^{\mathrm{b}}$ & $178.41^{\mathrm{c}}$ & $173.97^{\mathrm{c}}$ & $214.67^{\mathrm{a}}$ & $200.43^{\mathrm{ab}}$ & $220.21^{\mathrm{a}}$ & $210.22^{\mathrm{a}}$ \\
\hline & \pm 3.74 & \pm 3.74 & \pm 3.78 & \pm 3.42 & \pm 3.75 & \pm 3.47 & \pm 3.75 \\
\hline \multirow{2}{*}{$\begin{array}{l}\text { Lactating } \\
\text { does }\end{array}$} & $348.17^{b}$ & $337.74^{c}$ & $330.87^{c}$ & $378.43^{\mathrm{a}}$ & $370.46^{\mathrm{ab}}$ & $398.11^{\mathrm{a}}$ & $387.74^{\mathrm{a}}$ \\
\hline & \pm 4.94 & \pm 4.48 & \pm 4.74 & \pm 4.96 & \pm 4.73 & \pm 4.68 & \pm 4.11 \\
\hline
\end{tabular}

milk production may be due to the increasing in litter size at birth and at weaning (as presented in Table 5) since, there was positive correlation between litter size and milk yield (Rommers et al., 2004).

\section{Milk composition:}

Milk composition of does including the percentages of fat, protein, lactose, and ash is presented in Table 5. Results show that diets of does for biological treatments (fungus and bacteria) at most levels were significantly improved milk composition, that feeding the does on diets contained $15 \%$ 
EFFECT OF REPLACEMENT OF BERSEEM HAY WITH CONOCARPUS ON RABBITS 297 
$\mathrm{CO}+\mathrm{EM} 1$ and with 15 or $30 \% \mathrm{CO}+\mathrm{TR}$ significantly $(\mathrm{P} \leq 0.05)$ gave the highest milk content of dry matter, crude protein and fat compared to the other dietary treatments. CP ranged between 14.01- 16.86 vs. 15.00 for control diet, fat ranged between 15.12- 18.45 vs. 16.58 for a control diet. Regarding to significant increase in CP, Maertens (2009) reported that the protein-rich milk of rabbits provides primarily the essential amino acids for maintenance, tissue growth and at the same time provide a certain degree immune protection through the presence of specific whey proteins. This fact may be explain increase growth rate of kits and decrease their mortality rate from birth till weaning as shown in Table 7.

\section{Litter performance:}

Data in Table 6 show significant differences in litter size and weight of kits between groups. The performance of the litters followed that obtained with corresponding does, where diets with 15\% CO+EM1 and with 15 or $30 \% \mathrm{CO}+\mathrm{TR}$ significantly $(\mathrm{P} \leq 0.05)$ a cleaved the best figures for litter size of and weights from birth up to weaning that in turn revealed significant $(\mathrm{P} \leq 0.05)$ decreased in mortality rate $(\%)$ as compared to other dietary treatments. Additionally, large litter size post-reported that the effects may evoke great tactile stimulation of teats and indirectly enhance milk secretion through increased prolactin release (Lukefahr et al., 1983). The highest CP and fat content of does milk for biological treatments (fungus and bacteria) may be explain the rapid growth of kits at same treated (Table 6). Also, the significant increase in fat content with the biological treatments this may be support adequate fat stores for pregnant and lactation. Concerning the variations in mortality rate of kits between different treatments, untreated conocarpus (CO) groups showed significantly $(\mathrm{P} \leq 0.05)$ highest mortality rate, while biological treatments (fungus and bacteria) treated groups had the lowest rate (Table 7). Decreasing in mortality rate for young rabbits belong to treated groups during suckling period may be due to increase milk yield (Table 4).

Litter daily weight gains (LDWG) in different groups are shown in Table 7. Dietary levels of biological treatments (fungus and bacteria) at its highest levels with 15\% CO+EM1 and with 15 or $30 \%$ CO+TR significantly $(\mathrm{P} \leq 0.05)$ increased the LDWG. Also, these results may be discussed by Szendro et al. (2002) who reported that the milk production available per kit may be have a pronounced effect on the mortality of young rabbits. Besides that, decrease of mortality rate may be reflecting an increase of milk quality with treated diets by different levels of biological treatments (fungus and bacteria). Moreover decreasing of mortality rate 
EFFECT OF REPLACEMENT OF BERSEEM HAY WITH CONOCARPUS ON RABBITS 299 
could be attributed mainly to sufficient milk to cover litter requirements. In addition, Drummond et al. (2000) found that rabbit kits with high birth weight was grew faster and weight level increased stable over the 3 weeks. Also, these results might be due to the decreasing of anti nutritional factors (Tannins, Total phenols and oxalates) in diets contained CO+EM1 and $\mathrm{CO}+\mathrm{TR}$ which improved the growth performance and the milk production (Shakweer, 2003).

\section{Digestion coefficients of nutrients and nutritive value:}

Digestibility coefficients data presented in Table 8 indicated that the digestibility coefficient of different nutrients and nutritive values were increased insignificantly with biological treatments (fungus and bacteria) in different levels except total digestible nutrients (TDN) was improved significantly $(\mathrm{P} \leq 0.05)$ with biological treatments (fungus and bacteria) in different levels. Values of (TDN) were significantly $(\mathrm{P} \leq 0.05)$ improved with dietary manipulation especially with fungal enrichment. That, values of TDN ranged between 70.74-73.51 vs. 68.42 for a control diet, the best value was recorded for those which fed on diet contained $30 \%$ conocarpus treated by fungus .

The non-adverse effect of Conocarpus on digestibility coefficient of different nutrients and nutritive values may be due to the good balance of soluble and insoluble fibre which promotes gastrointestinal health (Swanson et al., 2001). Also, the improvement with biological treatments (fungus and bacteria) in different levels on TDN may be due to the effect of treatment that stimulate the digestive process, decreased anti nutritional factors and led to higher utilization efficiency of nutrients in the feed (Biondi et al., 1993 and Menaker et al.,2004).

\section{Economical efficiency:}

Data concerning economical evaluation are summarized in Table 9. The present results indicate an increase of net and relative revenue for rabbits fed on diets contained treated conocarpus with fungus or EM1 at all levels compared to those untreated. These results are in harmony with those of Abd- El Ghany et al. (2016) who reported that replacing 15\% and 30\% of berseem hay by biological treated conocarpus with fungus in growing rabbit's diet resulted in better economical efficiency.

\section{CONCLUSION:}

It could be concluded from the present study that replacing $15 \%$ and $30 \%$ of berseem hay by biological treated conocarpus with fungi (Trichoderma reesi) or Effective microorganisms $\left(\mathrm{EM}_{1}\right)$ in Baladi Black 
EFFECT OF REPLACEMENT OF BERSEEM HAY WITH CONOCARPUS ON RABBITS 303 
(BB) rabbit does diets, resulted in improve their reproduction performance without any adverse effect on physiological responses with high profitability under Egyptian conditions.

\section{REFERENCES}

A.O.A.C. (2000). Official Methods of Analysis 15th ed. Association of Official Analytical Chemists. Washington, DC., USA.

A.O.A.C. (2005). Association of Official Analytical Chemists. Official methods of analysis. $18^{\text {th }}$ Ed. Published by the AOAC, Washington, D. C., USA.

Abd- El Ghany, F.T.F., W.A.H. Ali, M.A. Mahmoud and L.F. AbdelMawla (2016). Effect of partial replacement of berseem hay by biologicaly treated. conocarpus on productive performance and physiological response of growing rabbits. The 9th International Poultry Conference of the Egyptian Poultry Science Associatiation, 7 - 10 November, 2016, Hurgada- EGYPT.

Abo-El-Ezz, Z.Z., A. Hassan and M. Samak (1981). Effect of litters size and mating cycles on lactation in rabbits. Alex. J. Agric. Res., 29: 75-82.

Agriculture Ministry Decree (1996). The standard properties for ingredients, feed additives and feed manufactured for animal and poultry. El-Wakaee El-Masria, No. 192 (1997) P 95 Amirria Press Cairo, Egypt.

Biondi,D., P.Cianci, C. Geraci, G. Ruberto and Piattelli (1993). Antimicrabial activity and chemical composition of essential oils from Sicilian aromatic plants. J.Flavour and Fragrance 8(6): 331337.

Castellini, C., A. Dal Bosco, M. Arias-Lvarez, P.L. Lorenzo, R. Cardinali and P.G. Rebollar (2010). The main factors affecting the reproductive performance of rabbit does: A review. Anim. Rep. Sci., 122: $174-182$.

Cheek, P.P. (1987). Rabbit Feeding and Nutrition. Orlando: Academic Press, Inc. Harcourt, Brace, Jovanovich, Publishers.

Cheeke, P.R.; N. Patton and G.S. Templton (1982).Rabbit Production.5th Edition. The Intersate Printers and Publishers DanvilleII.

Chrastinova, L., A. Sommer, J. Rafay and M. Svetlanska (1997). Avotan exploitation in rabbit nutrition. II. Nutrient digestibility and lactation performance of does rabbit. J. Farm Anim. Sci., 30: 80-86. 
Drummond, H., E. Vazquez, S. Sanchez-Colon, M. Martinez-Gomez and R. Hudson (2000). Competition for milk in the domestic rabbit: Survivors benefit from littermate deaths. Ethol., 106: 511-526.

Duncan, D.B. (1955). Multiple range and multiple F. test. Biometrics, 11: $1-42$.

El-Ashry, M.A., H.M. El-Sayed, M. Fadel, H.M. Metwally and M.M. Khorshed (2002). Effect of chemical and biological treatments of some crop residueson their nutritive value. Egypt. J. Nutrition and feed, 5(1): 43-54.

EL-Sayaad, G.A. (1994). A study on milk production of New Zealand White and Californian rabbits under Egyptian conditions. Egyptian J. Rabbit Sci., 4: 47-59.

EL-Sayaad, G.A. (2002). New feedstuffs resoureces in rabbit nutrition. Proc. $3^{\text {th }}$ Sci.Conf. on rabbit Prod. in Hot Climates, 8-11 October Hugada, Egypt. Pp: 461-467.

Fortun-Lamothe, L., T. Gidenne (2003). Besoins nutritionnels du lapereau et stratégies d'alimentation autour du sevrage. INRA Prod. Anim., 16:39-47.

Friggens, N.C. (2003). Body lipid reserves and the reproductive cycle: towards a better understanding. Livest. Prod. Sci,. 83: 209-226.

Gaafar, H.M.A., A.A. Ragab and K.F.A. El-Reidy (2014). Effect of diet supplemented with pumpkin (Cucurbita moschata) and black seed (Nigella sativa) oils on performance of rabbits: 1- Growth performance, blood haematology and carcass traits of growing rabbits. Rep. Opinion, 6: 52-59.

Gidenne T. (2000). Recent advance in rabbit nutrition : Emphasis on fibre requirements. World Rabbit Science, 8:23-32.

Linzell, J.L., M. Peaker and J.C. Taylor (1972). The effects of prolactin and oxytocin on milk secretion and on the permeability of the mammary epithelium in the rabbit. J. Physiol., 253:547.

Lukefahr, S., W.D Hohenboken, P.R. Cheeke and N.M. Patton (1983). Characterization of straightbred and crossbred rabbits for milk production and associative traits. J. Anim. Sci., 57: 1100-1107.

Maertens, L. (2009). Possibilities to reduce the feed conversion in rabbit production . In Proc.: Giornate di Coniglicoltura ASIC Forli, Italy, April 2-3, , pp. 1-10.

Menaker,A., M. Kravets, M. Koel and A. Orav (2004). Identification and characterization of supercritical fluid extracts from herbs. Comptes Rendus Chimie, (7): 629-633. 
Mohamed, A.H.; Fatma, T.F.Abd-Ghany and A.A.S Mahgoup(2016). Influence of supplementation of some trace minerals in form of nanoparticles on productive and reproductive performance of rabbit. Egyptian J. Nutrition and feeds, 19 (2):pp 325-335.

Munro, C.J. and G.H. Stabenfeldt (1984). Development of a microtiter plate enzyme immunoassay for the determination of pregnancy. $\mathrm{J}$. Endocr., 101:41-49.

Rowida, M. Riad, T.S.T. Seleem and D.S.E. Mohamed (2010). The relation between type of mating and reproductive performance of rabbit under Egyptian conditions. Proc 6th Inter. Con .on Rabbit Prod. in Hot Clim., Assuit, Egypt,pp 413- 426.

Rommers, J.M., R. Meijerhoft, J.P. Noordhuizen and B. Kemp (2004). Effect of feeding program during rearing and age at first insemination on performance during subsequent reproduction in young rabbit does. Reprod. Nutr. Dev., 44: 321-332.

SAS (2001). SAS /STAT User's Guide (Release 8.2). SAS Inst. Inc., Cary NC, USA.

Saman, E.; Q. Muhammad; A. Zainul and M. Ajmal Khan(2016). Secondary metabolites as anti-nutritional factors in locally used halophytic forage/fodder. Pakistan Journal of Botany 48(2):629-636.

Swanson, K.S., C.M. Grieshop, G.M. Clapper, R.G.Jr. Shields, T. Belay, N.R. Merchen and G.C.Jr. Fahey (2001). Fruit and vegetable fiber fermentation by gut microflora from canines. J.Anim.Sci., 79(4): 919-926.

Szendro, E., M. Gyovai, E. Biro-Nemeth, I. Radnai, Zs. Matics, Zs Nagy I. and Zs. Szendro, (2002). Effect of birth weight, milk supply status and feeding system on the mortality of suckling and growing rabbits. In Proc.: 3rd Sci. Conf. Rabbit Prod. in Hot Climates, 8-11 October, 2002, Hurghada, Egypt, pp. 401-407.

Van Socest, P.J. (1982). Nutritional ecology of ruminant $O$ and $B$ Books.Inc., Corvallis, Oredon. 112: 126-127.

Xiccato, G., A. Trocino, A. Sartori and P.I. Queaque (2004). Effect of parity order and litter weaning age on the performance and body energy balance of rabbit does. Livest. Prod. Sci., 85: 239-251. 


\section{تأثير الأحلال الجزئي لاريس البرسيم بالكونوكاربس (الامس)

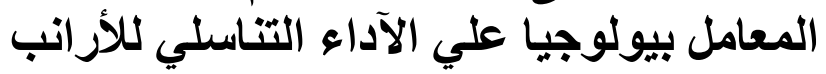

\section{وائل على حسن على - فاطمة طلعت فرج عبد الغنى - محمود عاطف محمود -

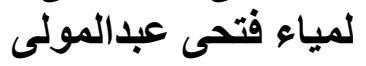 معهد بحوث الانتاج الحيوانى - مركز البحوث الزر اعية ـ- الدقى - مصر. أجريت التجربة بهدف دراسة تأثير الأحلال الجزئى لدريس البرسيم}

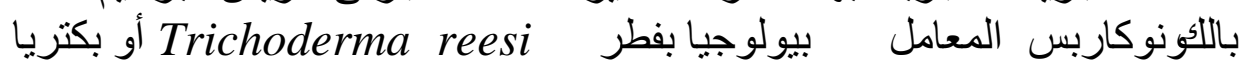

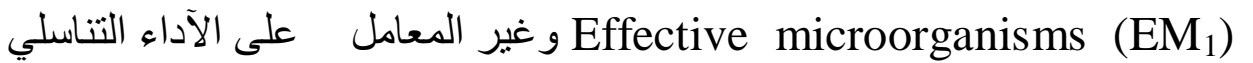

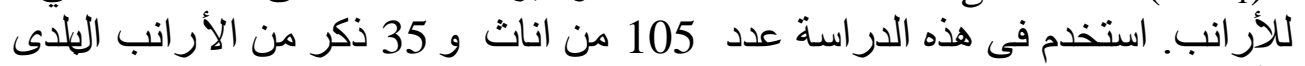

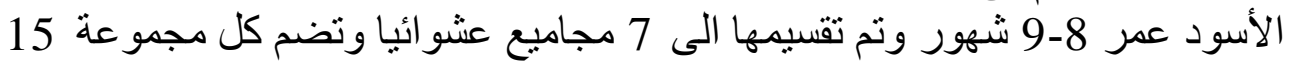

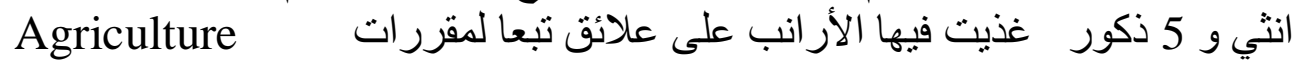

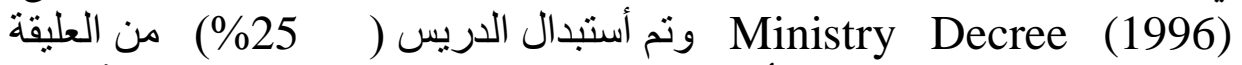

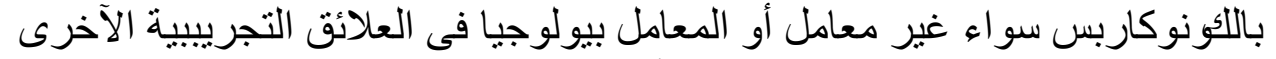

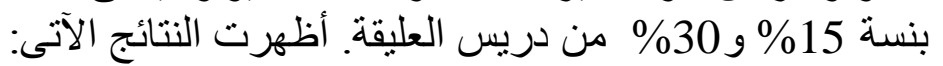

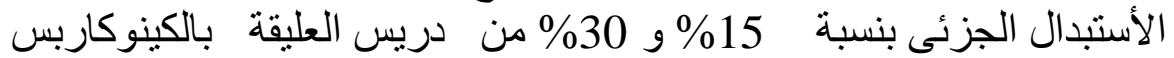

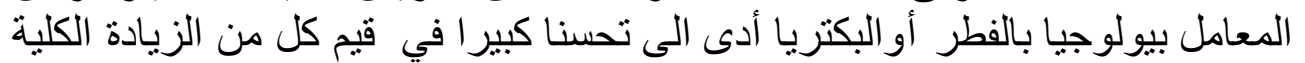

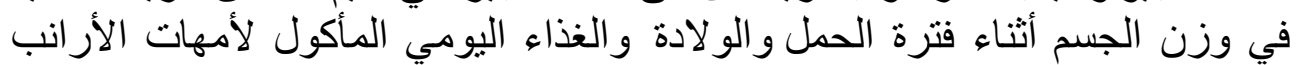

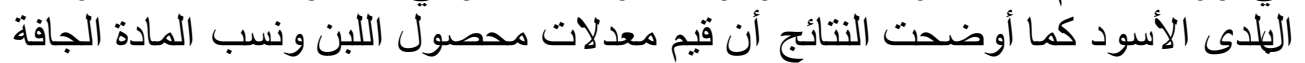

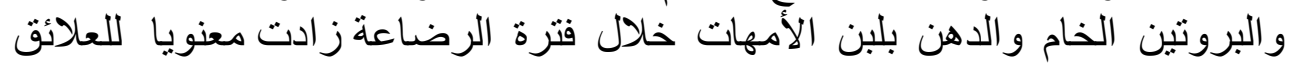

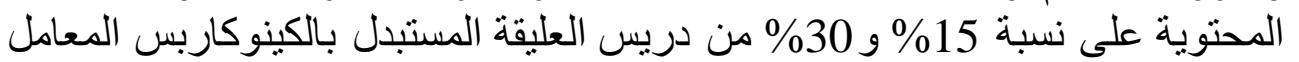

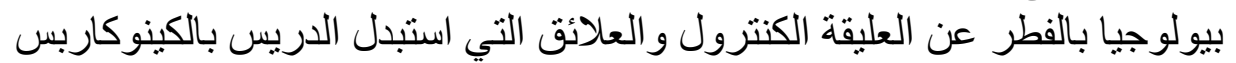

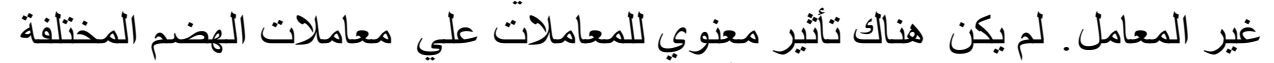

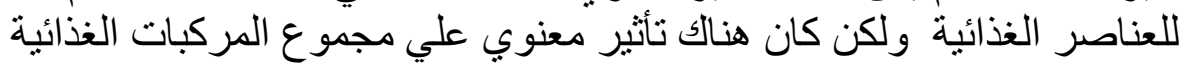

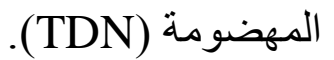
التوصية: امكانية الأستبدال الجزئى بنسبة 15\% و 30\% من دريس العليقة بالكينوكاربس المعامل بيولوجيا بفطر Trichoderma reesi أو بكتريا

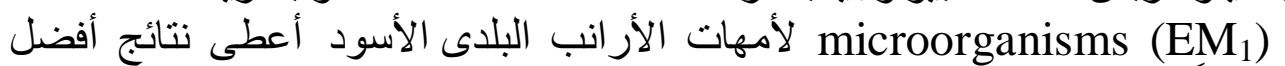

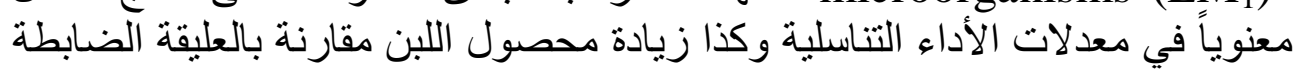
(المقارنة) مع تحسين العائد الاقتصادي. 